\title{
Leaf-litter decomposition in headwater streams: a comparison of the process among four climatic regions
}

\author{
Jesús Pozo ${ }^{1,10}$, Jesús Casas ${ }^{2,11}$, Margarita Menéndez ${ }^{3,12}$, Salvador Mollá, ${ }^{4,13}$, \\ Inmaculada Arostegui ${ }^{5,14}$, Ana Basaguren ${ }^{1,15}$, Carmen Casado ${ }^{4,16}$, \\ Enrique Descals ${ }^{6,17}$, Javier García-Avilés ${ }^{7,18}$, José M. González ${ }^{8,19}$, \\ Aitor Larrañaga $^{1,20}$, Enrique López ${ }^{2,21}$, Mirian Lusi ${ }^{2,22}$, Oscar Moya ${ }^{6,23}$ \\ Javier Pérez $^{1,24}$, Tecla Riera ${ }^{3,25}$, Neftalí Roblas ${ }^{9,26}$, AND M. Jacoba Salinas ${ }^{2,27}$ \\ ${ }^{1}$ Dpto. Biología Vegetal y Ecología, F. Ciencia y Tecnología, UPV/EHU, Apdo. 644, 48080 Bilbao, Spain \\ ${ }^{2}$ Dpto. Biología Vegetal y Ecología, Universidad de Almería, Ctra. Sacramento s/n, La Cañada, 04120 Almería, Spain \\ ${ }^{3}$ Dpto. Ecología, F. Biología, Universidad de Barcelona, Avda. Diagonal 645, 08028 Barcelona, Spain \\ ${ }^{4}$ Dpto. Ecología, F. Ciencias, Universidad Autónoma de Madrid, Darwin 2, 28049 Madrid, Spain \\ ${ }^{5}$ Dpto. Matemática Aplicada e Investigación Operativa, F. Ciencia y Tecnología, UPV/EHU, Apdo. 644, \\ 48080 Bilbao, Spain \\ ${ }^{6}$ Instituto Mediterráneo de Estudios Avanzados, IMEDEA (CSIC), Miquel Marqués 21, 07190 Esporles, Mallorca, Spain \\ ${ }^{7}$ Dpto. de Ecología, F. de Ciencias Biológicas, Universidad Complutense de Madrid, C/ José Antonio \\ Novais, 2, 28040 Madrid, Spain \\ ${ }^{8}$ Dpto. Biología y Geología, Universidad Rey Juan Carlos, C/ Tulipán, s/n, 28933 Móstoles, Madrid, Spain \\ ${ }^{9}$ Centro de Investigaciones Ambientales de la Comunidad de Madrid, Ctra. M-607 km 20, \\ 28760 Tres Cantos, Madrid, Spain
}

\begin{abstract}
The main purpose of our work was to elucidate factors responsible for the geographical differences in leaf-litter decomposition rates in Spanish oligotrophic headwater streams. Decomposition experiments with alder (Alnus glutinosa) leaf litter were carried out in 22 headwater streams in 4 different climatic regions across the Iberian Peninsula (Cornisa Cantábrica, Cordillera Litoral Catalana, Sierra de Guadarrama, and Sierra Nevada). Streams that were similar in size, flowed mainly over siliceous substrate in catchments with scarce human settlements and activities, and fell within a range of low nutrient concentrations were chosen in each region. Breakdown rates were regionally variable and were low (0.109$0.198 \%$ ash-free dry mass [AFDM]/degree day [dd]) in the Cornisa Cantábrica, the most mesic and Atlantic region, and high $(0.302-0.639 \% \mathrm{AFDM} / \mathrm{dd})$ in Sierra de Guadarrama, one of the coldest and most inland areas. Temperature was not the determining factor affecting differences in breakdown rates among regions, and breakdown rates were not related to concentrations of dissolved nutrients. However, microbial reproductive activity (sporulation rates) was significantly correlated with dissolved $\mathrm{P}$ concentration. Breakdown rates were explained better by presence and feeding activities of detritivores than by decomposer activity. Incorporation of breakdown rates in assessment schemes of stream ecological status will be difficult because leaf processing does not respond unequivocally to environmental factors when climatic regions are considered. Thus, regional adjustments of baseline standards in reference conditions will be required.
\end{abstract}

Key words: leaf litter, decomposition, headwater streams, invertebrates, fungi, eutrophication, Spain.

${ }^{10}$ E-mail addresses: jesus.pozo@ehu.es

11 jjcasas@ual.es

12 mmenendez@ub.edu

13 salvador.molla@uam.es

14 inmaculada.arostegui@ehu.es

15 ana.basaguren@ehu.es

16 c.casado@uam.es

17 ieaedc@uib.es

18 ciam03@bio.ucm.es
19 jmgonzalez@escet.urjc.es

20 aitor.larranagaa@ehu.es

21 emlopez@ual.es

22 mirianlusi@hotmail.it

23 oscarmoyamesa@gmail.com

24 javier.perezv@ehu.es

25 triera@porthos.bio.ub.es

${ }^{26}$ neftali.roblas@madrid.org

27 mjsalina@ual.es 
Fluvial ecosystems have been impaired by and continue to deteriorate because of a wide array of human impacts of varying magnitude, ranging from severe alterations with conspicuous effects to subtle and cryptic modifications. Headwater streams, which represent $>95 \%$ of the total number of stream segments (Wallace and Eggert 2009), are less affected by humans than other water bodies and are crucial reservoirs of biodiversity. A critical step in preserving or improving the integrity of a river (sensu Karr 1991) is to assess its ecological status adequately with methods sensitive enough to determine the consequences of human effects or to guarantee the success of eventual restoration actions. Traditional evaluations of river health rely on physicochemical characteristics (Müller et al. 2008, Fu et al. 2009) or on structural properties of community diversity and composition of several taxonomic groups, mainly macroinvertebrates, algae, or macrophytes (Barbour et al. 1999, De Jonge et al. 2008, Demars and Edwards 2009).

Recently, ecologists have advocated use of functional components of the ecosystem to evaluate river health and have argued that, in some cases, stressors might change function but not structure (Moulton 1999, Bunn and Davies 2000, Brooks et al. 2002, Gessner and Chauvet 2002, Riipinen et al. 2009, Young et al. 2008). Moss (2008) pointed out that ecological quality is measured accurately by paying attention primarily to the intactness of several fundamental characteristics of ecosystem function rather than to secondary characteristics, such as particular concentrations of substances or species composition.

This controversy of structural vs functional indicators seems to be implicit in the European Water Framework Directive (WFD) (2000/60/EC). An apparent contradiction, noticed by Moss (2008), exists between the definition of a high ecological status of aquatic ecosystems and the instructions given in the WFD on the way that ecological status is to be determined or improved. A high ecological status embraces fundamental characteristics (ecosystem function), but the instructions encourage focus on secondary details (mainly taxonomic structure) and, hence, may undermine the fundamental improvement of aquatic ecosystems that was intended (Moss 2008).

Leaf-litter decomposition in streams is a functional ecosystem variable that integrates the activity of several phylogenetic groups (Gessner and Chauvet 2002, Young et al. 2008). The rate of leaf-litter decomposition depends on natural factors, such as climate, geology, altitude, and latitude, and responds strongly to changes in environmental variables (e.g., temperature, $\mathrm{pH}$, dissolved $\mathrm{O}_{2}$, nutrients, sediments, riparian vegetation) caused by anthropogenic distur- bance (Webster et al. 1995, Molinero et al. 1996, Pozo et al. 1998, Niyogi et al. 2003, Elosegi et al. 2006, Sampaio et al. 2008).

Eutrophication is one of the most widespread human effects on inland waters (Withers and Jarvie 2008). Studies on stream eutrophication generally demonstrate that dissolved nutrients enhance decomposition rates of leaf litter by increasing microbial activity (e.g., Suberkropp and Chauvet 1995, Gulis and Suberkropp 2003, Greenwood et al. 2007), at least under moderate nutrient enrichment. However, the effects on macroinvertebrate colonization and leaflitter consumption seem to be more variable, which could be a result of the community variability between regions or a possible response to other pollutants in eutrophic streams (e.g., Pascoal et al. 2003). Furthermore, the effect of eutrophication on stream ecosystem processes can depend on factors other than $\mathrm{P}$ or $\mathrm{N}$ supplies, such as temperature and flow regimes, substrate, and C supply (Dodds 2007, Withers and Jarvie 2008), which may vary naturally within and across regions (Casas et al. 2006). Therefore, natural variation may hinder the application of functional indices aimed at comparing the effect of eutrophication across different geographical and climatic settings. According to Karr and Chu (1999), an understanding of the baseline of natural variation is the foundation for precise assessment of change caused by humans. Attempts have been made to evaluate ecosystem functioning based on leaf decomposition across large geographical areas (Irons et al. 1994, Young et al. 2004, Lecerf et al. 2007, McKie et al. 2008, Woodward 2009, Hladyz et al. 2010, Pérez et al. 2011). The aim of our study was to compare leaf-litter processing in small headwater streams slightly affected by nutrient enrichment among 4 different geographic and climatic areas of the Iberian Peninsula (Cornisa Cantábrica, Cordillera Litoral Catalana, Sierra de Guadarrama, and Sierra Nevada). We hypothesized that: 1) large-scale abiotic conditions (especially temperature) would influence biotic contributors to leaf breakdown and, therefore, differences in decomposition rates among regions, and 2) leaf-litter processing would respond positively to dissolved nutrients through enhancement of microbial activity.

\section{Methods}

\section{Study sites}

The study was conducted in 22 low-order streams in the Iberian Peninsula: 6 in the north (Cornisa Cantábrica [CC]), 4 in the northeast (Cordillera Litoral Catalana [CLC]), 7 in the center (Sierra de Guadarrama [SG]), and 5 in the south (Sierra Nevada [SN]) 
(Fig. 1, Table 1). In each area, streams were similar in size and flowed mainly over siliceous substrate in catchments with scarce human settlements and activities (Table 1). Annual precipitation and mean temperature varied among regions from 310 to $923 \mathrm{~mm}$ and from 9.0 to $16.4^{\circ} \mathrm{C}$, respectively, and changed with altitude (Table 1). Streams from CC and CLC were more mesic than those of SG and SN, which were at higher altitudes. The Gorzynski Continentality Index (GCI) was used as a measure of continentality (i.e., climatic gradient) of the geographic areas and for comparative purposes. It is calculated as GCI $=1.7(M i-m i) / \sin (L a t)-2.4$, where $M i$ and $m i$ are the highest and the lowest mean monthly temperatures $\left({ }^{\circ} \mathrm{C}\right)$, respectively, and Lat is latitude in degrees (www.globalbioclimatics.org). Values were: 7.7 (CC), 17.1 (CLC), 23.6 (SG), and 32.0 (SN). Streams draining larger catchments were chosen to avoid temporary streams in the drier regions. Streams differed in catchment area, but most streams had a mean channel width $<5 \mathrm{~m}$ (Table 1 ).

Groups of streams spanned a range of low dissolved nutrient concentrations (particularly $\mathrm{P}$, $<50 \mu \mathrm{g} \mathrm{PO}_{4}-\mathrm{P} / \mathrm{L}$ ) in each area. Streams within this low and narrow eutrophication gradient were difficult to locate in SG and SN because of the sharp transition from oligotrophic to severe eutrophic conditions caused by organic pollution (wastewater). Therefore, in these areas, only streams with low nutrient contents were sampled. As a consequence, nutrient gradients in these areas were lower and narrower than in the other 2 areas. Dispersed human settlements and extensive farming in some areas in northern Spain (CC, CLC) allowed us to meet the required low nutrient-enrichment gradients.

\section{Water variables}

Water temperature was monitored continuously with ACR Smart-Button (ACR Systems Inc., Surrey, British Columbia) or HOBO Pendant (Onset Computer Corporation, Bourne, Massachusetts) temperature loggers throughout the study period (autumn-winter 2007-2008) in all streams. Conductivity, $\mathrm{pH}$, and dissolved $\mathrm{O}_{2}$ (WTW multiparametric sensor) were measured in situ, and water samples were taken for nutrient analyses on each sampling date $(n=6)$. Nutrient analyses were done on water filtered through precombusted glass-fiber filters (Whatman GF/F). $\mathrm{NO}_{3}{ }^{-}$concentration was determined by ion chromatography (COMPACT IC1.1; Metrohm, Herisau, Switzerland) or with the sodium salicylate method (Monteiro et al. 2003). $\mathrm{NH}_{4}^{+}$was measured with the manual salicylate method (Krom 1980),

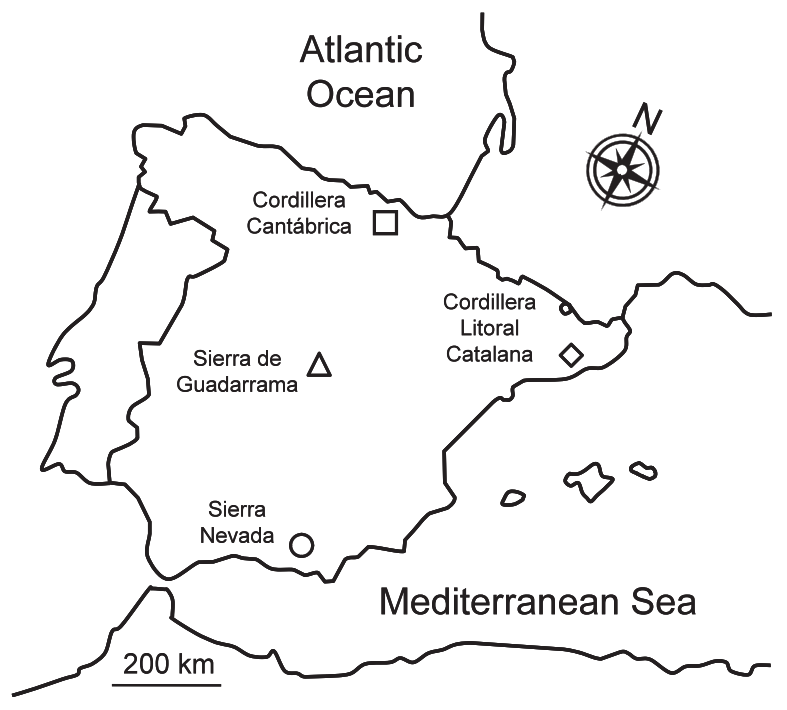

FIG. 1. Locations of the 4 study regions in the Iberian Peninsula: Cordillera Cantábrica (CC), Cordillera Litoral Catalana (CLC), Sierra de Guadarrama (SG), and Sierra Nevada (SN).

$\mathrm{NO}_{2}{ }^{-}$with the sulphanylamide method, soluble reactive $\mathrm{P}(\mathrm{SRP})$ with the molybdate method, and alkalinity through titration to an end $\mathrm{pH}$ of 4.5 (APHA 2005).

\section{Litter bags and decomposition}

Alder (Alnus glutinosa (L.) Gaertner) leaves were used as a standard substrate to measure decomposition rates. All leaf litter used was collected in CC to prevent local differences in the initial quality of materials (Lecerf and Chauvet 2008b). Leaves were collected from the forest soil just after abscission in autumn 2007 and air-dried to constant mass. Five grams $( \pm 0.25)$ of alder leaves were weighed, moistened (spray), and enclosed in mesh bags $(15 \times$ $20 \mathrm{~cm}, 5-\mathrm{mm}$ mesh). Leaf bags (25 in each stream) were tied with nylon lines to iron bars driven into the stream bed along 50-m reaches. Extra sets of 5 bags were immersed in the streams for $24 \mathrm{~h}$ and used to correct the initial mass values for leaching. Such a correction is made to better describe processing dynamics once labile compounds have disappeared from leaves (Suberkropp and Chauvet 1995, Ferreira et al. 2006). Leaf incubation was initiated in late autumn (November-December) 2007 to coincide with the seasonal peak in leaf fall.

Five bags were retrieved after $7 \mathrm{~d}(\mathrm{t} 7)$ and at dates that roughly corresponded to losses of 20 (t20), 35 (t35), 50 (t50), and 70\% (t70) of the initial mass, as estimated from exponential decomposition rates $(k)$ recalculated from previous data at each experimental 


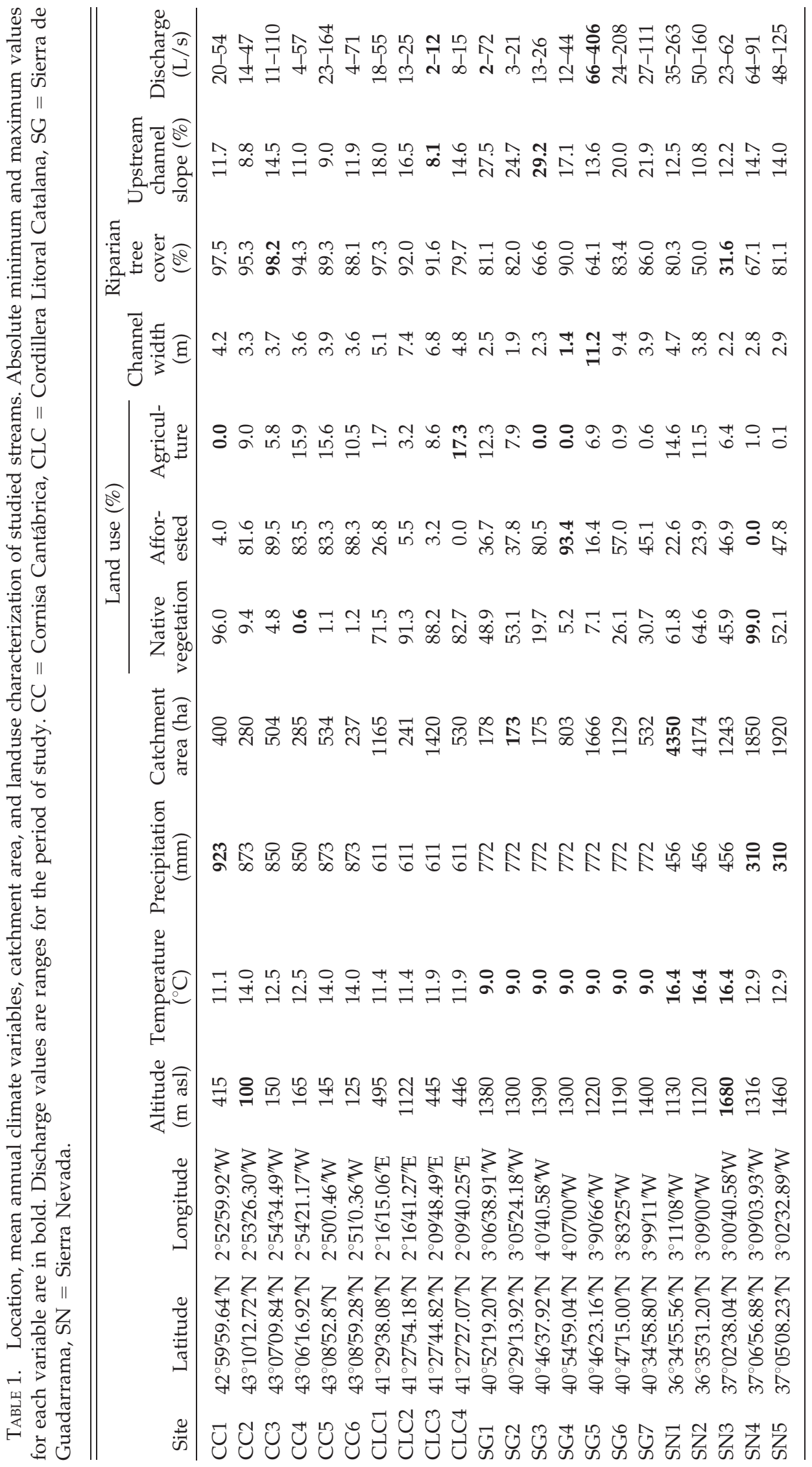


site (Mendoza-Lera et al. 2010). t70 was achieved between 46 (SG) and 113 (CLC) d. Initial mass refers to initial ash-free dry mass (AFDM) corrected for leaching. After retrieval, litter bags were placed in individual plastic bags and transported in refrigerated containers to the laboratory where they were processed immediately. Leaf material from each bag was rinsed with filtered stream water, and the fauna and mineral particles were separated from the leaf litter on a $200-\mu \mathrm{m}$ sieve. Only fauna from $\mathrm{t} 50$ samplings, which generally coincided with colonization peaks in alder leaves (Hieber and Gessner 2002), were preserved in $70 \%$ ethanol for later analysis. Invertebrates were identified to family level under a dissecting microscope, counted, and sorted into functional feeding groups (the most representative for the family) according to Merritt and Cummins (1996) and Tachet et al. (2002). Fungal sporulation rate was determined at t20 (2-3 wk after immersion), which often coincides with the peak of conidial production on alder leaves (Pascoal and Cássio 2004), from 1 set of 5 leaf disks (12-mm diameter) punched from each bag with a cork borer (see below). The remaining leaf material was, as on the other sampling dates, ovendried $\left(70^{\circ} \mathrm{C}, 72 \mathrm{~h}\right)$ and weighed. A portion was used for nutrient analyses, and the rest was combusted $\left(550^{\circ} \mathrm{C}, 4 \mathrm{~h}\right)$ to determine AFDM.

Leaf material for nutrient analyses $(C, N$, and $P$ ) was ground into fine powder (1-mm screen). $C$ and $\mathrm{N}$ were determined with a Perkin Elmer series II CHNS/O elemental analyser (Perkin Elmer, Norwalk, Connecticut). P was determined spectrophotometrically after mixed acid digestion (molybdenum blue method; Allen et al. 1974). Results were expressed as $\%$ leaf-litter dry mass (DM) as it was analyzed and as molecular elemental ratios (C:N, C:P, and N:P).

\section{Sporulation of aquatic hyphomycetes $(A H)$}

Leaf disks from each bag from t20 were incubated in 100-mL Erlenmeyer flasks with $25 \mathrm{~mL}$ of filtered stream water (Whatman GF/F) on a shaker (60 rpm) for $48 \mathrm{~h}$ at $10^{\circ} \mathrm{C}$. The resulting conidial suspensions were transferred into $50-\mathrm{mL}$ centrifuge tubes and fixed with $2 \mathrm{~mL}$ of $37 \%$ formalin. An aliquot of the suspension was filtered (Millipore SMWP $5-\mu \mathrm{m}$ pore size) for conidial identification and counting. Each filter was stained with trypan blue in lactic acid $(0.05 \%)$, and conidia were identified (after Gulis et al. 2005 and species description protologues) and counted under a microscope at $250 \times$. Counting effort was reduced with the assistance of voice recognition and Excel data-entry generator software developed by one of us (OM). Leaf-disk DM was determined as described above for the bulk leaf material. Sporulation rates were expressed as number of conidia produced per $\mu \mathrm{g}$ leaf DM per day of in vitro incubation time.

\section{Statistical analyses}

The relationship between \% AFDM remaining (response variable) and elapsed time (predictor variable) was fitted to linear $\left(M_{t}=M_{0}-b t\right)$ and exponential models $\left(M_{t}=M_{0} e^{-k t}\right)$, where $M_{0}$ is the initial AFDM corrected for leaching, $M_{t}$ is the remaining AFDM at time $t$, and $b$ is the linear and $k$ the exponential decomposition rate. Streams differed in temperature (Table 2), so breakdown rates were calculated with each model in terms of time (d) and accumulated heat, the sum of mean daily temperatures accumulated by the sampling day (degree days [dd]) (Stout 1989). The goodness of fit of the models was evaluated by calculating the coefficient of determination $\left(R^{2}\right)$ after expressing the values of the response variable of both models in the same original scale (Kvålseth 1985, Quinn and Keough 2002). Slopes (breakdown rates) were compared with nested analysis of covariance (ANCOVA; \%AFDM as dependent variable, streams nested within region and region as factors, and dd as covariate). The ANCOVA model was considered as a particular case of a linear mixed model to account for the correlation resulting from the clustered design of successive measurements at each site (Verbeke and Molenberghs 2000). The model was fitted using the method of restricted maximum likelihood (REML), and the covariance structure used was a $1^{\text {st }}$-order autoregressive (AR[1]). For other variables (e.g., invertebrates, sporulation rates), comparisons were carried out by nested analysis of variance (ANOVA; streams nested within region and region as factors; sampling time was a factor when leaf nutrient content was compared). Subsequent pairwise comparisons were made with Tukey's test (Zar 2010).

The influence of several variables that could be potential predictors of the breakdown rate also was tested. Simple linear regression was fitted independently for all variables with the breakdown rate as response variable. Region could have influenced the relationships between the selected variables and the breakdown rate, so these regressions were repeated with region as a factor, and the significance of the covariate in the resulting ANCOVA was examined. Simple linear regression and correlation were used when searching for relationships between variables other than breakdown rate. The Shapiro-Wilk test was used to assess normality, and transformation was done when necessary. An $\operatorname{arcsine}(x)$ transformation 





was applied to percentage data, and $\sqrt{ }(x)$ or $\log (x)$ transformations were used in the other cases. All analyses were undertaken with SPSS 17.0 (SPSS Inc., Chicago, Illinois) and SAS 9.2 (SAS Institute Inc., Cary, North Carolina).

\section{Results}

Nutrient levels were relatively low (Table 2), but water physicochemical variables differed noticeably within and among regions (nested ANOVA, $p<0.05$; Table 3). The highest values of physicochemical variables were found in $\mathrm{CC}$, the most oceanic region according to the GCI (see Study sites), whereas the lowest were registered in SG and $\mathrm{SN}$, the most continental ones.

Alder-leaf mass loss corrected for leaching (mean leaching loss $\approx 18 \%$ ) fit a linear model better than an exponential model in terms of $\mathrm{d}\left(R^{2}\right.$ values higher in all 22 cases) and dd ( $R^{2}$ higher in 21 of 22 cases) (Table 4). The linear rate based on $\mathrm{dd}$, which corrected for interregional temperature differences, was used for analyses of spatial variation and relationships to environmental variables. Breakdown rates (\% mass lost/dd) differed significantly among and within regions (nested ANCOVA, $p<0.001$; Table 5) and were high in SG, intermediate in SN, and low in CLC and CC.

The initial quality of the leaf material was the same for every stream (\% composition \pm SE before leaching, $n=5$ : $\mathrm{C}=47.1 \pm 1.3 ; \mathrm{N}=2.48 \pm 0.14 ; \mathrm{P}$ $=0.081 \pm 0.003)$. Percent $C$ varied little throughout the study (mean CV for all sites $\approx 5 \%$ ). However, $\mathrm{N}$ and $\mathrm{P}$ varied noticeably (mean $\mathrm{CV} \approx 10 \%$ for $\mathrm{N}$ and $20 \%$ for P). As a consequence, variation observed for $\mathrm{C}$ :nutrient ratios mainly depended on changes in $\mathrm{N}$ or $\mathrm{P}$ in the leaf material. Furthermore, C:nutrient ratios tended to decrease as the dissolved nutrient concentration (both $\mathrm{N}$ and P) increased (Fig. 2A, B), but differences among regions were not significant (nested ANOVA, $p>0.05$ ). At 19 of 22 sites, leaves lost $P$ relative to $C$, but this loss decreased as the dissolved $\mathrm{P}$ increased (Fig. 2A). In contrast, at all sites, leaves gained $\mathrm{N}$ relative to $\mathrm{C}$, i.e., mean $\mathrm{C}: \mathrm{N}$ decreased during processing. This $\mathrm{N}$ enrichment increased as dissolved $\mathrm{N}$ increased in streams (Fig. 2B).

Mean $\mathrm{AH}$ sporulation rates differed greatly among and within regions (nested ANOVA, $p<0.01$, SG $=$ $\mathrm{SN}<\mathrm{CLC}=\mathrm{CC})$. Values ranged from $<0.01$ conidium $\mu \mathrm{g}^{-1} \mathrm{~d}^{-1}$ (SG) to close to 6 (CC) (Table 6) and were positively correlated with variables related to dissolved solids, such as alkalinity $(r=0.747, p<$ $0.01)$, conductivity $(r=0.726, p<0.01)$ and SRP $(r=$ $0.532, p<0.05)$, and temperature $(r=0.558, p<0.01)$.
A total of 42 identifiable taxa of $\mathrm{AH}$ were found (Table 6): 28 in CC, 25 in CLC, 23 in SN, and 19 in SG. The 4 regions had 9 species in common, and Flagellospora curvula was dominant.

Macroinvertebrate abundance differed among and within regions (nested ANOVA, $p<0.001$, SG $<$ CLC $<\mathrm{SN}=\mathrm{CC}$ ) and was represented by 49 families: 41 in CC, 31 in SN, 27 in SG, and 19 in CLC (Table 7). Shredders were represented by 11,9, 9, and 7 families, respectively, and were an important component of macroinvertebrate assemblages in terms of abundance in all regions (Table 7).

Linear regression analyses between breakdown rate and associated variables showed that conductivity, alkalinity, $\mathrm{pH}$, sporulation rate (negative slope), and channel slope (positive) were the most important predictors of breakdown rate (Table 8). Several variables had extreme values in SG, so regressions were repeated with region as a factor. Conductivity was the most significant variable explaining breakdown rate (Table 8), and the region factor was not significant $(p=0.205)$. Channel slope, shredder density (positive), and alkalinity (negative) were the other variables significantly related to the decay rate (Table 8). Thus, the significant effect of shredders on leaf processing appeared when the influence of region was corrected. Furthermore, when sites from SG were excluded from the regression analysis without region as a factor, the significant effect of shredders also was clear (Fig. 3). The negative highly significant relationship between sporulation rate and breakdown rate was clearly influenced by region and disappeared when the regression was adjusted by region (Table 8). No positive relationships were found between nutrients and breakdown rate. However, the effect of microbial activity on breakdown rate appeared to depend on concentrations of dissolved nutrients (see results of elemental ratios above).

\section{Discussion}

The main goal of our work was to elucidate factors responsible for regional differences in leaf-litter decomposition rates among oligotrophic headwater streams. Headwater streams in our study were similar and drained siliceous catchments within a narrow low-to-moderate range of dissolved nutrient concentrations, particularly P. Despite the similarities among streams, inter- and intraregional differences in watercolumn physicochemical characteristics were apparent. In general, nutrient concentrations and their variability decreased with altitude.

Before identifying relationships between leaf processing and environmental variables it was necessary 
TABLE 3. Results of the nested analyses of variance for physicochemical variables during the experiments. SRP $=$ soluble reactive $P$.

\begin{tabular}{|c|c|c|c|c|c|}
\hline Variable & Source of variation & $\mathrm{df}_{1}$ & $\mathrm{df}_{2}$ & $F$ & $p$ \\
\hline & Site(region) & 18 & 95 & 8.26 & $<0.001$ \\
\hline & Site(region) & 18 & 95 & 8.07 & $<0.001$ \\
\hline \multirow[t]{2}{*}{$\mathrm{NH}_{4}^{+}$} & Region & 3 & 18 & 10.08 & $<0.001$ \\
\hline & Site(region) & 18 & 95 & 3.58 & $<0.001$ \\
\hline \multirow[t]{2}{*}{$\mathrm{NO}_{3}^{-}$} & Region & 3 & 18 & 3.38 & 0.041 \\
\hline & Site(region) & 18 & 95 & 17.86 & $<0.001$ \\
\hline \multirow[t]{2}{*}{$\mathrm{pH}$} & Region & 3 & 18 & 41.47 & $<0.001$ \\
\hline & Site(region) & 18 & 95 & 17.52 & $<0.001$ \\
\hline \multirow{2}{*}{ Alkalinity } & Region & 3 & 18 & 14.12 & $<0.001$ \\
\hline & Site(region) & 18 & 95 & 60.33 & $<0.001$ \\
\hline Conductivity & Region & 3 & 18 & 20.04 & $<0.001$ \\
\hline
\end{tabular}

to calculate breakdown rates according to the model that yielded the best fits. In many studies, leaf breakdown is an exponential function of elapsed time (Webster and Benfield 1986, Abelho 2001), but in our study, the correction for leaching resulted in better fits with single linear regressions. Therefore, we focused on linear instead of exponential rates. Exponential rates also are reported because they are frequent in the literature (Irons et al. 1994, Lecerf and Chauvet 2008b).

As expected, breakdown rates were noticeably variable within and among regions. Increases in temperature are assumed to enhance biological activities, leaf processing included (Webster and Benfield 1986, Bergfur 2007). However, contrary to our hypothesis, temperature was not a determining factor of breakdown rate. The fastest rates, regardless of the model used for their calculation, were found where mean water temperature and accumulated heat (dd) were the lowest (SG). The range of mean water temperatures among sites (2.7-10.1) should have been great enough to generate important differences in the activity of detritivores and decomposers and in leaflitter processing rates (Friberg et al. 2009). However, as has been noted in other studies (Fleituch and Leichtfried 2007), other factors must have masked its effects. Gonçalves et al. (2006) found faster decay rates in a temperate stream than in a Mediterranean stream (both on the Iberian Peninsula) or a Neotropical stream. They suggested that the differences might be related to consumer efficiency and proposed that biological differences overrode the temperature effect.

If using degree-days eliminates the effect of differing thermal regimes, rates should be similar across latitudes, unless other factors are involved
(Irons et al. 1994). When we expressed breakdown rates on a degree-day basis, differences between regions with the warmest and the coldest streams were even greater, as has been observed by others (Hladyz et al. 2010). Thus, other factors in our study were more important than temperature in determining breakdown rates. Similarly, rates $(/ \mathrm{dd})$ were much faster in an Alaskan stream than in streams in Costa Rica and Michigan (Irons et al. 1994), results suggesting that interregional differences in litter breakdown rates, as in our study, are not merely consequences of shifts in water temperature.

The main factors significantly related to leaf breakdown rate were conductivity, alkalinity (negatively), and channel slope (positively). The negative relationship between decay rate and conductivity (or alkalinity) is difficult to explain, and positive relationships are more frequent in the literature (Young et al. 2008). We did find opposite trends at some sites (data not shown), but when the regression analysis was adjusted by region the significant relationship persisted. The negative relationship between decay rate and conductivity might be, in part, an indirect consequence of the effect of channel slope on decay rate because both variables were highly correlated. Channel slope affects water velocity and particle transport, which contribute to physical abrasion on leaves, accelerating leaf fragmentation (Paul et al. 2006) and masking the effect of moderate dissolved nutrient concentration in headwaters (Spänhoff et al. 2007). The importance of physical abrasion on leaf breakdown is context dependent, and some authors have reported that the effect of physical abrasion is trivial compared with the effects of biotic drivers 
TABLE 4. Mean (SE) leaf-litter breakdown rates, linear $b$ and exponential $k$, of alder leaves in terms of time (d) and accumulated heat (degree days [dd]). Bold indicates maximum site $R^{2}$.

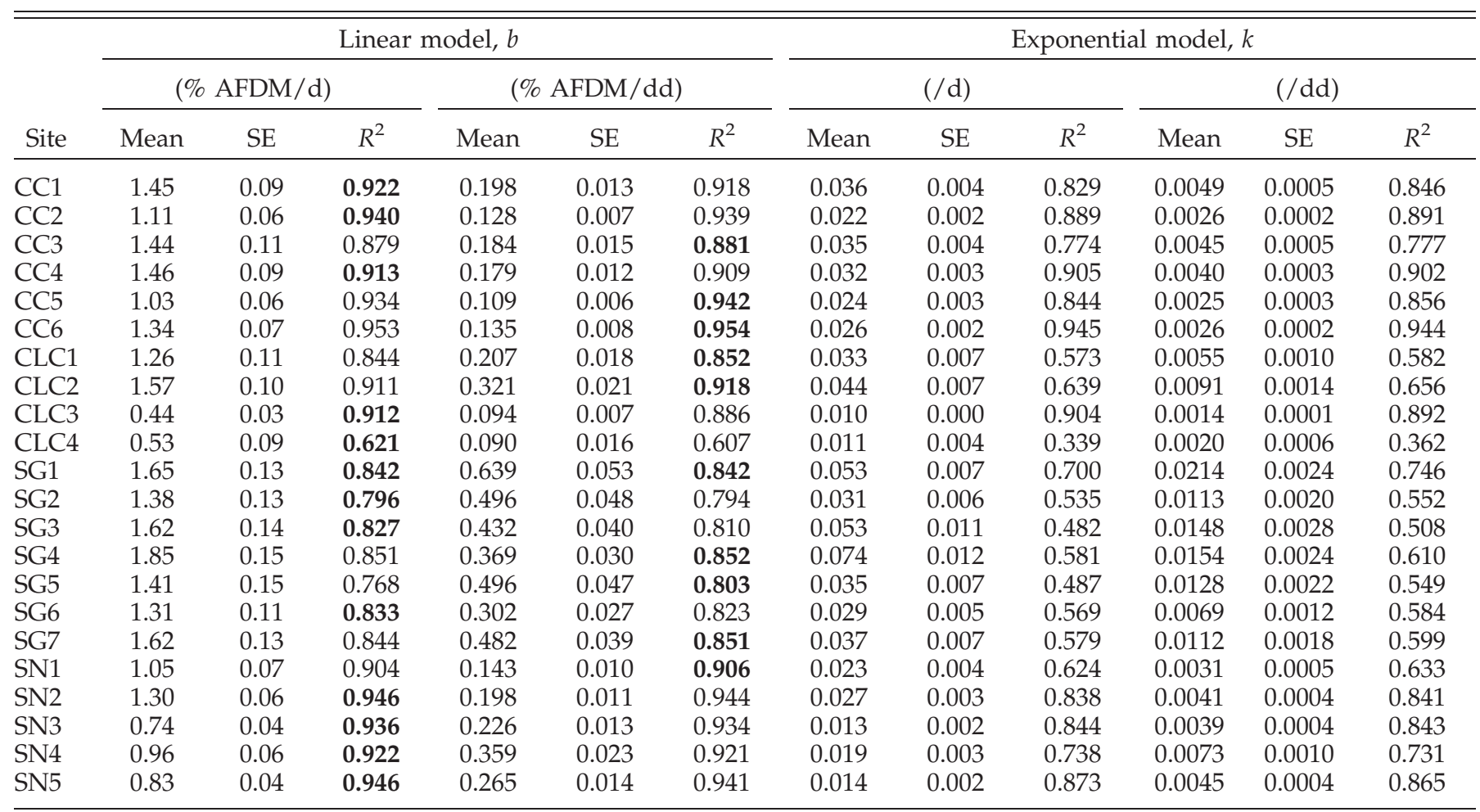

(Hieber and Gessner 2002, Ferreira et al. 2006, Hladyz et al. 2009). In our study, the significance of channel slope diminished and that of shredders appeared when the analysis was corrected by region (Table 8). In contrast, particle sedimentation is a factor commonly suggested to slow leaf breakdown because deposition of fine sediment on litterbags can limit microbial and macroinvertebrate activity (Zweig and Rabeni 2001, Niyogi et al. 2003, Rabeni et al. 2005,
Mesquita et al. 2007, Spänhoff et al. 2007) and, thus, reduce processing rates. We only have indirect measures of this effect (\% ash content of leaf litter in the bags), but the significant negative regression between ash content and breakdown rate point to a negative effect of fine sediment on leaf processing.

Shredder density positively influenced breakdown rates when SG data were excluded from the regression analyses. The order of mean shredder densities
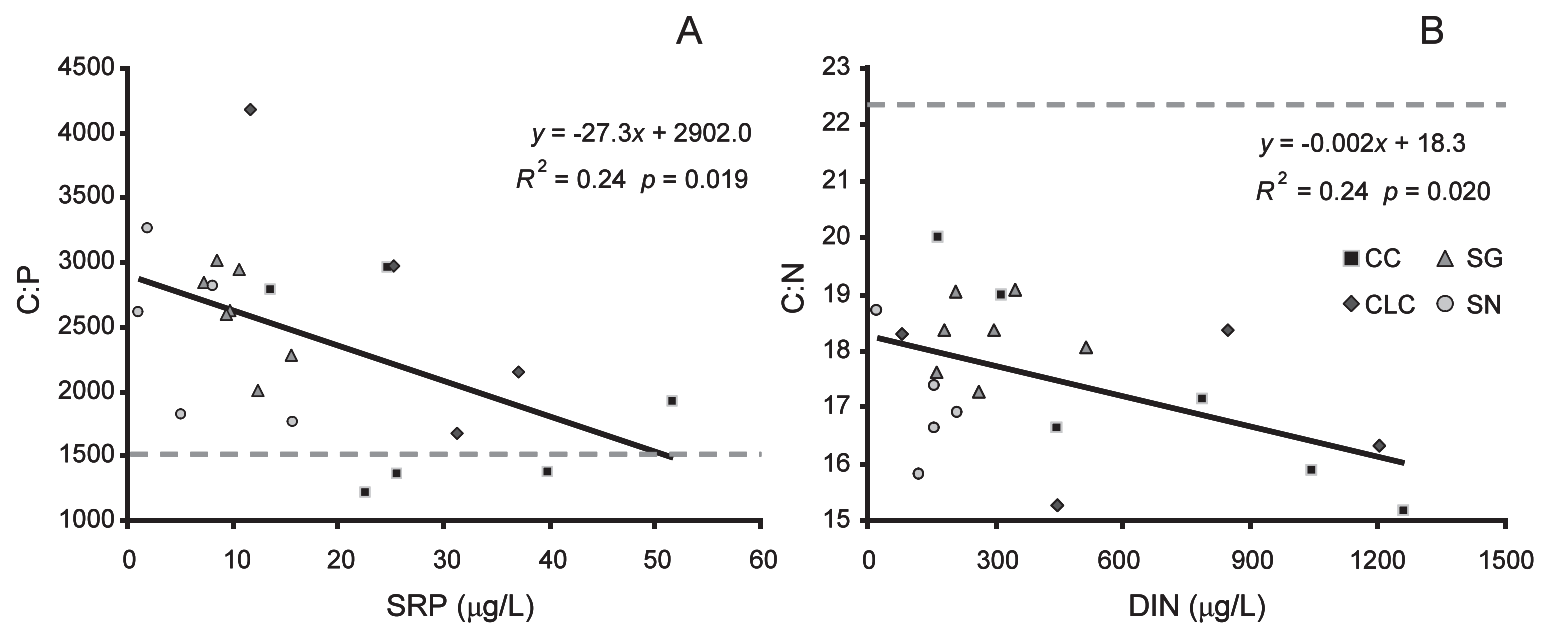

FIG. 2. Relationship between alder C:nutrient ratio (molecular elemental ratio) and soluble reactive P (SRP) (A), dissolved inorganic N (DIN) (B). Broken lines correspond to the value of each C:nutrient ratio in leaves before leaching. 
TABLE 5. Results of the nested analysis of covariance for the linear rates in terms of degree days.

\begin{tabular}{lccrc}
\hline \hline $\begin{array}{l}\text { Source of } \\
\text { variation }\end{array}$ & $\mathrm{df}_{1}$ & $\mathrm{df}_{2}$ & \multicolumn{1}{c}{$F$} & \multicolumn{1}{c}{$p$} \\
\hline $\begin{array}{l}\text { Degree days } \\
\begin{array}{l}\text { Region } \times \\
\text { degree days }\end{array}\end{array}$ & 1 & 528 & 3607.1 & $<0.001$ \\
$\begin{array}{c}\text { Site(region) } \times \\
\text { degree days }\end{array}$ & 18 & 528 & 198.9 & $<0.001$ \\
\hline
\end{tabular}

among the 3 regions was opposite that of mean conductivities, indicating that headwaters usually had low conductivity concurrent with greater shredder density (relationship not statistically significant).

The highest breakdown rates in our study occurred in SG and $\mathrm{SN}$, the regions with the coldest temperatures and the lowest nutrient levels. Irons et al. (1994) suggested the relative importance of invertebrates vs microorganisms changes along a latitudinal gradient, with invertebrates more important in colder waters at high latitudes (or high altitudes). If this suggestion is correct, shredders should play a decisive role on leaf breakdown in SG and SN, especially if, as in our case, fungal activity were limited (indicated by low sporulation rates). Some investigators have shown that cold waters can favor some shredders like stoneflies and caddisflies that are adapted to cooler thermal regimes (Danks 2007). This situation could exert a key role on leaf processing and would help explain the faster breakdown rates in the colder areas. Caddisflies and stoneflies were well represented in SG and SN.

The degree of eutrophication of our streams was low, but we expected leaf breakdown rates to respond to increases in dissolved nutrients because of enhanced microbial activity (Pozo 1993, Suberkropp and Chauvet 1995, Gulis and Suberkropp 2003). However, neither dissolved nutrients $(\mathrm{N}$ and $\mathrm{P})$ nor sporulation rate were positively related to breakdown rate. Poor relationships between leaf breakdown rates and water-column nutrients have been found elsewhere. For instance, in a study done along a gradient of water-column nutrient enrichment in south-central Sweden, Bergfur (2007) found little support for the conjecture that decomposition rates were related to nutrient enrichment. Perhaps, the potential effects of eutrophication in our low-nutrient, low-variability system were overridden by other factors with more important interregional variation, such as density of shredders.

Sporulation rates were positively related to dissolved solids (alkalinity, conductivity, and SRP) but not with breakdown rate (sporulation rates were highest where breakdown rates were lowest). Sporu- lation rates were measured only on one occasion for each stream, but we assumed that the values could be compared. The time elapsed from implantation to t 20 differed among regions, but, in most cases (20 of 22), it was 12 to $23 \mathrm{~d}$, a period of high fungal spore production (including peaks) by $\mathrm{AH}$ when a great amount of the incubated leaf litter still remains (Chauvet et al. 1997). This period seems to coincide with the growth phase of mycelia (measured as ergosterol) on leaf litter (Pozo et al. 1998). The relationships between fungal activity, nutrient availability, and leaf decomposition in nutrient-poor waters are probably complex, but the effects on elemental ratios of leaf litter probably are related to microbial activity. All leaves used in the experiments came from the same location, so the variations in leaf quality ( $\mathrm{N}$ and $\mathrm{P}$ content) during breakdown were in response to the local availability of dissolved nutrients. Nevertheless, quality acquired (as C:N, C:P, and $\mathrm{N}: \mathrm{P}$ ) and processing rates measured were not parallel. According to Artigas et al. (2008), fungal N demands for sporulation can be fulfilled at levels of dissolved $\mathrm{NO}_{3}{ }^{-}<300 \mu \mathrm{g} \mathrm{N} / \mathrm{L}$, and no enhancement should be expected with increased dissolved nutrients. However, in streams with low concentrations of dissolved inorganic $\mathrm{N}(<40 \mu \mathrm{g} / \mathrm{L})$ and $\mathrm{P}(<16 \mu \mathrm{g} / \mathrm{L})$, leaf decomposition and sporulation rates were stimulated only when both nutrients were added together, which suggests that these nutrients potentially colimited fungal activity (Grattan and Suberkropp 2001). Grattan and Suberkropp (2001) also reported that when N concentrations were $>65 \mu \mathrm{g} / \mathrm{L}$, decomposition and sporulation rates were stimulated by addition of $\mathrm{P}$ to waters with $\mathrm{P}$ concentrations $<5 \mu \mathrm{g} / \mathrm{L}$. In our study, dissolved $\mathrm{NO}_{3}-\mathrm{N}$ was $>65 \mu \mathrm{g} / \mathrm{L}$ in most cases, and mean dissolved $\mathrm{PO}_{4}-\mathrm{P}$ created a gradient from $<5 \mu \mathrm{g} / \mathrm{L}$ to $52 \mu \mathrm{g} / \mathrm{L}$. These concentrations were high enough to elicit a response in both decomposition and sporulation rates according to Grattan and Suberkropp (2001), but we observed a response only of sporulation rates. In more eutrophic streams, microbial breakdown rate and spore production are not predictable. Both positive and negative effects have been reported in the literature, but a reduction of species richness of $\mathrm{AH}$ involved in leaf processing is often observed in eutrophic streams (Lecerf and Chauvet 2008a). In our study, differences in $\mathrm{AH}$ species richness might not be a consequence of impairment but of natural forces because SG, a region characterized by its nutrient-poor waters, circumneutral $\mathrm{pH}$, and low temperature, had the lowest richness.

On the other hand, the enhancement of breakdown rates by increases in dissolved nutrients seems to depend on leaf quality (Molinero et al. 1996), which could explain why the decay rate of a high-quality 
TABLE 6. Sporulation rates (minimum-maximum) for each aquatic hyphomycete taxon or form (no. $\mu \mathrm{g}^{-1}$ leaf dry mass $\mathrm{d}^{-1}$ ). Site abbreviations are given in Table 1.

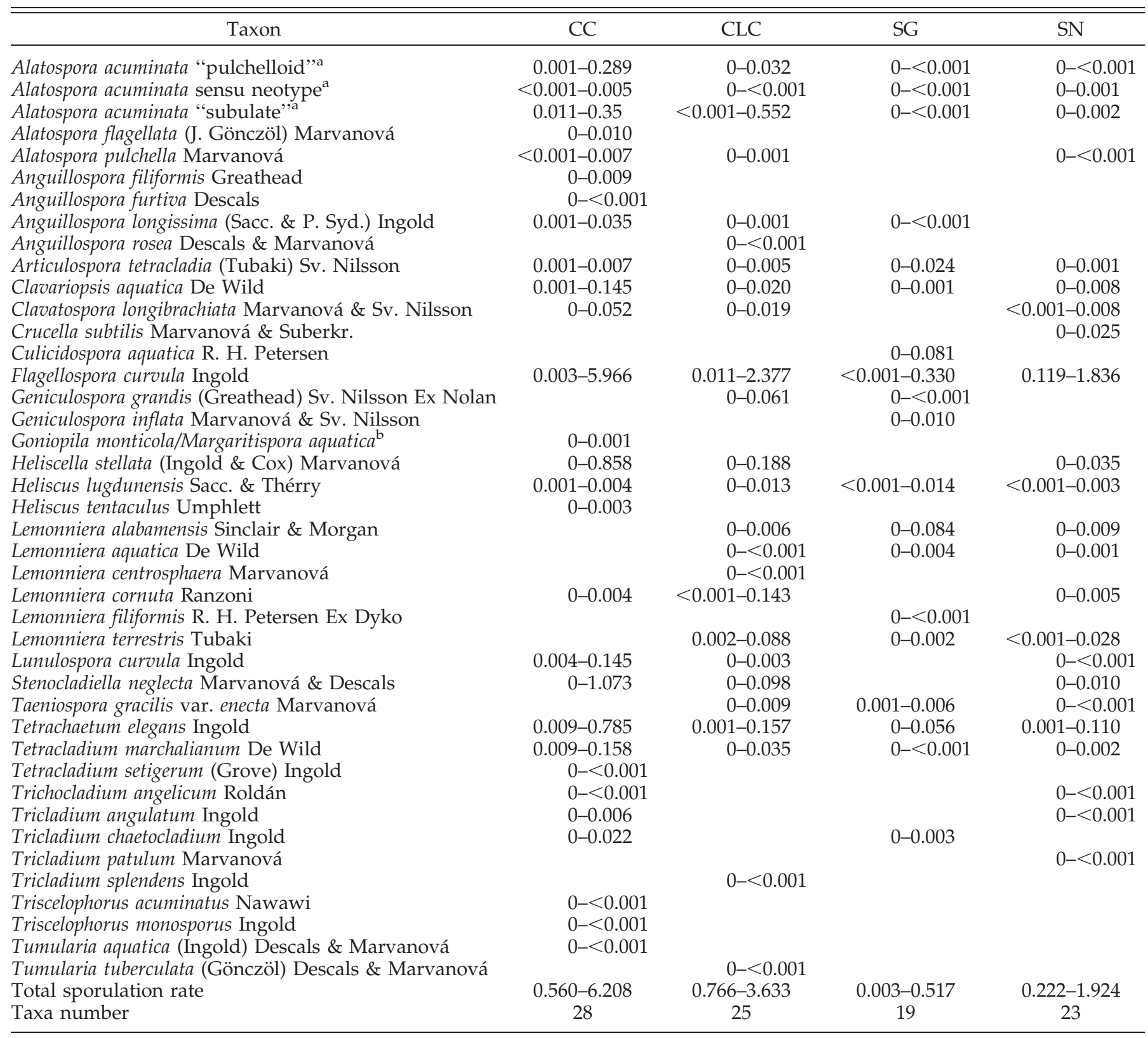

a Alatospora acuminata Ingold 1942 was described without a type. Marvanová and Descals (1985) later detected 2 strains in culture, which have clearly distinguishable conidia. They included both in A. acuminata and referred to them as "sensu stricto" (which the authors designated as neotype) and "sensu lato". However, the bracketed terms above may cause confusion because, by definition, the "sensu stricto" concept should be included in "sensu lato" and this is not the case here, where conidial shapes of both strains do not overlap. We conclude that A. acuminata sensu neotype should be kept as such, the category "sensu stricto" being redundant, and we propose to replace the term "sensu lato" by "pulchelloid", because its conidia strongly resemble those of A. pulchella. We recognize a 3 rd conidial shape of what could belong to A. acuminata. It is readily recognized by its strikingly subulate, unconstricted stalk, and we refer to it as "subulate". This shape is relatively abundant in our samples and at many other sites in the lberian Peninsula and elsewhere, including Hungary (J. Gönczöl, Hungarian National Museum, Budapest, personal communication) and possibly Australia. Pure culture and molecular studies underway will determine whether these 2 forms, pulchelloid and subulate, may be the basis for erecting formal taxa, and whether they should be included in $A$. acuminata. We included both forms as separate categories under A. acuminata to avoid losing potentially valuable ecological information.

b Records of conidia of Goniopila monticola (Dyko) Marvanová \& Descals and of typical conidia of Margaritispora aquatica Ingold are lumped because the conidia are indistinguishable on nitrocellulose filters and overlap in size. Atypical forms of the latter species have not been detected in our samples. 
TABle 7. Range of per site mean densities of invertebrate families collected from bags (no./g ash-free dry mass). Families are ordered by mean density within each functional group (FG). CC = Cornisa Cantábrica, CLC = Cordillera Litoral Catalana, SG $=$ Sierra de Guadarrama, SN = Sierra Nevada, Shr = shredder, Col = collector, Gat = gatherer, Filt $=$ filterer, Scr $=$ scraper, Pred $=$ predator.

\begin{tabular}{|c|c|c|c|c|c|c|}
\hline Family & Order & FG & $\mathrm{CC}$ & CLC & SG & SN \\
\hline Limnephilidae & Trichoptera & Shr & $0-1.64$ & $0-25.46$ & $1.16-19.53$ & $0.13-13.92$ \\
\hline Leuctridae & Plecoptera & Shr & $0-8.09$ & $0-2.04$ & $0-7.62$ & $1.52-28.29$ \\
\hline Gammaridae & Crustacea & Shr & $0-49.89$ & $0-2.15$ & & \\
\hline Nemouridae & Plecoptera & Shr & $0-2.38$ & $0-17.38$ & $0-4.78$ & $0-13.16$ \\
\hline Sericostomatidae & Trichoptera & Shr & $0-0.84$ & $0-27.06$ & 0-10.09 & $0-0.10$ \\
\hline Dryopidae & Coleoptera & Shr & & & & $0.52-15.93$ \\
\hline Lepidostomatidae & Trichoptera & Shr & & & $0-6.11$ & 0-8.35 \\
\hline Capniidae & Plecoptera & Shr & $0-4.81$ & & $0-1.88$ & $0.12-3.07$ \\
\hline Tipulidae & Diptera & Shr & $0-0.46$ & $0-1.54$ & $0-1.21$ & $0.12-0.86$ \\
\hline Limoniidae & Diptera & Shr & $0-0.86$ & $0-0.48$ & $0-0.41$ & $0-1.22$ \\
\hline Taeniopterygidae & Plecoptera & Shr & $0-0.13$ & & $0-0.14$ & \\
\hline Odontoceridae & Trichoptera & Shr & $0-0.14$ & & & \\
\hline Asellidae & Crustacea & Shr & $0-0.11$ & & & \\
\hline Chironomidae & Diptera & Col-Gat & $17.63-540.36$ & $13.27-56.64$ & $0-6.41$ & $66.31-182.83$ \\
\hline Oligochaeta & Oligochaeta & Col-Gat & $1.41-80.48$ & 0-1.65 & $0-0.63$ & $0.46-27.77$ \\
\hline Leptophlebiidae & Ephemeroptera & Col-Gat & $0-4.32$ & $0-4.05$ & $0-3.68$ & \\
\hline Psychodidae & Diptera & Col-Gat & $0-0.27$ & $0-0.21$ & $0-0.41$ & $0.33-11.63$ \\
\hline Ephemerellidae & Ephemeroptera & Col-Gat & $0-3.53$ & & $0-0.16$ & \\
\hline Heptageniidae & Ephemeroptera & Col-Gat & $0-0.63$ & & & $0-1.61$ \\
\hline Caenidae & Ephemeroptera & Col-Gat & $0-1.58$ & & & $0-0.51$ \\
\hline Dixidae & Diptera & Col-Gat & $0-0.16$ & & & $0-0.12$ \\
\hline Stratiomyidae & Diptera & Col-Gat & $0-0.13$ & & & \\
\hline Hydropsychidae & Trichoptera & Col-Filt & $0-1.65$ & $0-2.55$ & $0-0.82$ & $2.09-24.85$ \\
\hline Simuliidae & Diptera & Col-Filt & $0-26.40$ & & $0-1.10$ & $0-4.14$ \\
\hline Brachycentridae & Trichoptera & Col-Filt & & & & $0-6.95$ \\
\hline Philopotamidae & Trichoptera & Col-Filt & & & $0-0.09$ & $0-2.17$ \\
\hline Hydrobiidae & Mollusca & Scr & $0.13-56.86$ & & & \\
\hline Ancylidae & Mollusca & Scr & $0-2.50$ & & & \\
\hline Scirtidae & Coleoptera & Scr & $0-1.56$ & & $0-0.79$ & $0-0.72$ \\
\hline Goeridae & Trichoptera & Scr & & & $0-0.48$ & \\
\hline Valvatidae & Mollusca & Scr & $0-0.24$ & & & $0-0.24$ \\
\hline Glossosomatidae & Trichoptera & Scr & $0-0.22$ & & & \\
\hline Baetidae & Ephemeroptera & Col-Gat-Scr & $1.83-19.01$ & $0-4.69$ & $0-0.47$ & $2.28-24.50$ \\
\hline Elmidae & Coleoptera & Col-Gat-Scr & $0-1.82$ & & $0-0.16$ & $0-4.75$ \\
\hline Hydraenidae & Coleoptera & Col-Gat-Scr & $0-1.90$ & & $0-0.16$ & \\
\hline Planariidae & Turbellaria & Pred & $0-2.32$ & & $0-4.29$ & $0-17.25$ \\
\hline Perlidae & Plecoptera & Pred & & $0-14.10$ & $0-0.09$ & \\
\hline Empididae & Diptera & Pred & $0-9.78$ & $0-0.10$ & & $0.21-3.65$ \\
\hline Polycentropodidae & Trichoptera & Pred & $0-7.41$ & & & $0-0.22$ \\
\hline Athericidae & Diptera & Pred & $0-1.13$ & $0-0.70$ & $0-0.09$ & \\
\hline Rhyacophilidae & Trichoptera & Pred & $0-0.53$ & & $0-0.26$ & $0-1.55$ \\
\hline Ceratopogonidae & Diptera & Pred & $0-0.47$ & & & $0-0.58$ \\
\hline Chloroperlidae & Plecoptera & Pred & $0-0.39$ & $0-0.40$ & $0-0.65$ & \\
\hline Dytiscidae & Coleoptera & Pred & $0-0.15$ & $0-0.53$ & & $0-0.25$ \\
\hline Hydrophilidae & Coleoptera & Pred & & $0-0.42$ & & \\
\hline Cordulegasteridae & Odonata & Pred & $0-0.46$ & & & $0-0.11$ \\
\hline Aeschnidae & Odonata & Pred & $0-0.28$ & & & \\
\hline Calopterygidae & Odonata & Pred & & & & $0-0.17$ \\
\hline Perlodidae & Plecoptera & Pred & $0-0.16$ & & & \\
\hline Total shredders & & & $0.75-50.68$ & $0-46.38$ & $7.93-29.10$ & $3.86-73.36$ \\
\hline Total invertebrates & & & $57.92-683.30$ & $21.67-121.56$ & $10.85-38.30$ & $114.47-271.29$ \\
\hline Family number & & & 41 & 19 & 27 & 31 \\
\hline
\end{tabular}




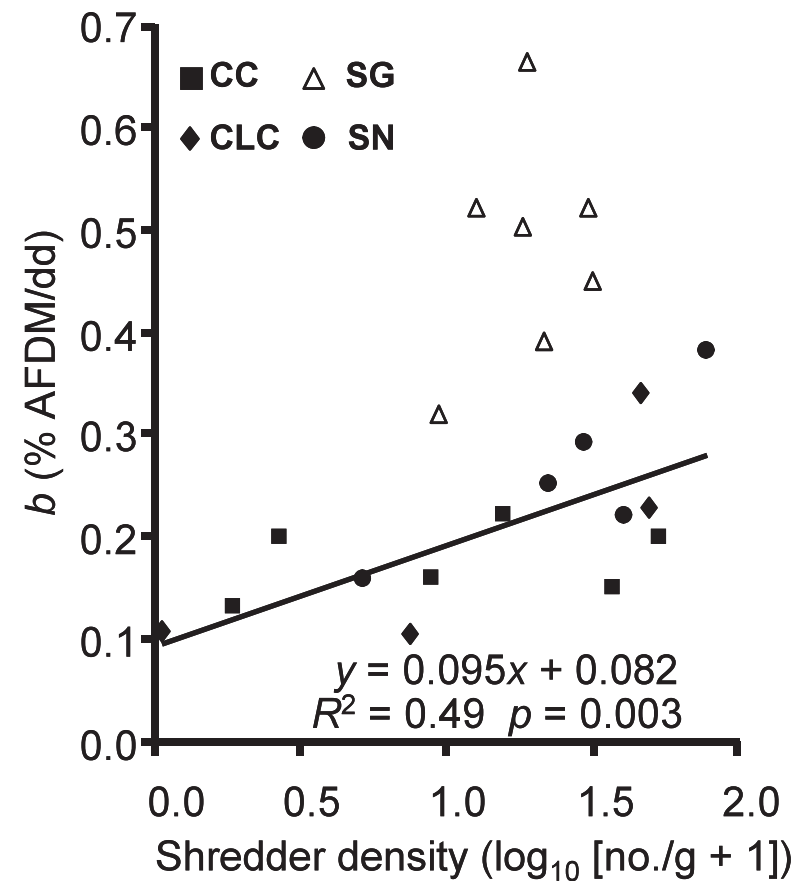

FIG. 3. Relationship between alder breakdown rate $(b)$ and shredder density. Data from Sierra de Guadarrama (SG) were excluded from the regression. AFDM = ash-free dry mass, $\mathrm{dd}=$ degree day.

leaf species such as alder is less influenced than others by dissolved nutrients (Pozo et al. 1998, Hladyz et al. 2010). However, alder leaf litter decay is sensitive to a slight eutrophication when fine-mesh bags are used for incubations and to changes in riparian vegetation in nutrient-poor waters when coarse-mesh bags are used (Elosegi et al. 2006), results suggesting that this species is sensitive to the activity of both decomposers and detritivores under different stressors. The responses of other species of poor quality (e.g., oak) to moderate eutrophication tend to be higher but later than responses of alder (Gulis et al. 2006), results consistent with the slower decomposition rates of oak leaves. Ferreira et al. (2006) showed that several indicators of the decomposition process respond faster in alder than in oak leaves (e.g., changes in nutrient content, fungal biomass, and sporulation peaks). Thus, alder leaf litter could be considered a better candidate than leaves with slower decay for assessing impacts on stream functioning because it responds faster and its use reduces the risk of bag loss caused by floods.

In conclusion: 1) temperature was not the determining factor for differences in breakdown rates among regions nor did rates increase with dissolved nutrients; 2) microbial activity (i.e., sporulation rates) was related to dissolved $\mathrm{P}$, but the effect of nutrients on leaf breakdown rates was negligible; and 3) variability in shredder density explained the geographical differences in breakdown rates, but their role was masked by other factors (e.g., channel slope) locally. Last, incorporation of breakdown rates into assessment schemes of stream ecological status might be hindered by the absence of unequivocal responses of leaf processing to variations of environmental factors among different geographical/climatic regions. Precise use of this functional metric would

TABLE 8. Summary of the regression analyses between the potential explanatory variables and the leaf-litter breakdown rate not adjusted and adjusted by region (analysis of covariance) (right). Sign of the slope is indicated. Asterisks $\left(^{*}\right)$ highlight models in which the region factor significantly affects the variable.

\begin{tabular}{|c|c|c|c|c|c|c|}
\hline Variables & \multicolumn{3}{|c|}{ Unadjusted model } & \multicolumn{3}{|c|}{ Adjusted model } \\
\hline Conductivity & - & 0.786 & $<0.001$ & - & 0.837 & 0.004 \\
\hline Channel slope & + & 0.644 & $<0.001$ & + & 0.789 & $0.040^{*}$ \\
\hline $\mathrm{pH}$ & - & 0.481 & $<0.001$ & + & 0.743 & $0.277^{*}$ \\
\hline Sporulation rate & - & 0.438 & $<0.001$ & - & 0.732 & $0.610^{*}$ \\
\hline Total invertebrate density & - & 0.256 & 0.016 & + & 0.754 & $0.194^{*}$ \\
\hline Shredder density & + & 0.159 & 0.066 & + & 0.797 & $0.028^{*}$ \\
\hline Shredder richness & + & 0.148 & 0.077 & + & 0.753 & 0.201 \\
\hline SRP & - & 0.127 & 0.104 & + & 0.734 & 0.543 \\
\hline Nitrate & - & 0.112 & 0.127 & - & 0.747 & 0.265 \\
\hline Nitrite & - & 0.104 & 0.144 & - & 0.729 & 0.780 \\
\hline
\end{tabular}


require regional adjustments of baseline standards in reference conditions.

\section{Acknowledgements}

This study was funded by the Spanish Ministry of Education and Science (project CGL2007-66664-C04), by the University of the Basque Country (Research grant GIU05/38), and by the Basque Government (Research grants IT-422-07 and IT-302-10). We are grateful to Nadia Arkarazo, Aingeru Martínez, Fernando Rodríguez, Carolina Rozas, and Roberto Velilla for help with field and laboratory work. We thank the 'Cuenca Alta del Manzanares' Regional Park, the Peñalara Natural Park, the Gorbeia Natural Park, the Montseny Natural Park, and the Sierra Nevada Natural-National Park for sampling permits and assistance, and also acknowledge the Spanish Meteorological Agency (AEMET) for providing data on temperature and rainfall.

\section{Literature Cited}

Abelho, M. 2001. From litterfall to breakdown in streams: a review. TheScientificWorld 1:656-680.

Allen, S. E., H. M. Grimshaw, J. A. Parkinson, and J. A. Quarmby. 1974. Chemical analysis of ecological materials. Blackwell Scientific, Oxford, UK.

APHA (American Public Health Association). 2005. Standard methods for the examination of water and wastewater. $22^{\text {nd }}$ edition. American Public Health Association, American Waterworks Association, Water Environment Federation, Washington, DC.

Artigas, J., A. M. Romaní, And S. Sabater. 2008. Effect of nutrients on the sporulation and diversity of aquatic hyphomycetes on submerged substrata in a Mediterranean stream. Aquatic Botany 88:32-38.

Barbour, M. T., J. Gerritsen, B. D. SNYder, AND J. B. Stribling. 1999. Rapid bioassessment protocols for use in streams and wadeable rivers: periphyton, benthic macroinvertebrates and fish. $2^{\text {nd }}$ edition. EPA 841-B-99-002. Office of Water, US Environmental Protection Agency, Washington, DC.

BERGFUR, J. 2007. Seasonal variation in leaf-litter breakdown in nine boreal streams: implications for assessing functional integrity. Fundamental and Applied Limnology 169:319-329.

Brooks, S. S., M. A. Palmer, B. J. Cardinale, C. M. Swan, and S. RibBlett. 2002. Assessing stream ecosystem rehabilitation: limitations of community structure data. Restoration Ecology 10:156-168.

BunN, S. E., AND P. M. DAvies. 2000. Biological processes in running waters and their implications for the assessment of ecological integrity. Hydrobiologia 422:61-70.

Casas, J. J., M. O. Gessner, P. Langton, D. Calle, E. Descals, AND M. J. SAlinas. 2006. Diversity of patterns and processes in rivers of eastern Andalusia. Limnetica 25: $155-170$.

Chauvet, E., E. Fabre, A. Elósegui, and J. Pozo. 1997. The impact of eucalyptus on the leaf-associated aquatic hyphomycetes in Spanish streams. Canadian Journal of Botany 75:880-887.

DANKS, H. V. 2007. How aquatic insects live in cold climates. Canadian Entomologist 139:443-471.

De Jonge, M., B. Van de Vijver, R. Blust, and L. Bervoets. 2008. Responses of aquatic organisms to metal pollution in a lowland river in Flanders: a comparison of diatoms and macroinvertebrates. Science of the Total Environment 407:615-629.

Demars, B. O. L., AND A. C. Edwards. 2009. Distribution of aquatic macrophytes in contrasting river systems: a critique of compositional-based assessment of water quality. Science of the Total Environment 407:975-990.

DodDs, W. K. 2007. Trophic state, eutrophication and nutrient criteria in streams. Trends in Ecology and Evolution 22:669-676.

Elosegi, A., A. Basaguren, And J. Pozo. 2006. A functional approach to the ecology of Atlantic Basque streams. Limnetica 25:123-134.

Ferreira, V., V. Gulis, and M. A. S. Graça. 2006. Wholestream nitrate addition affects litter decomposition and associated fungi but not invertebrates. Oecologia (Berlin) 149:718-729.

Fleituch, T., AND M. Leichtfried. 2007. Electron transport system (ETS) activity in alder leaf litter in two contrasting headwater streams. International Review of Hydrobiology 92:378-391.

Friberg, N., J. B. Dybijaer, J. S. Olafsson, G. M. Gislason, S. E. LARSEN, AND T. L. LAURIDSEN. 2009. Relationships between structure and function in streams contrasting in temperature. Freshwater Biology 54:2051-2068.

Fu, G., D. Butler, and S. T. KHu. 2009. The impact of new developments on river water quality from an integrated system modelling perspective. Science of the Total Environment 407:1257-1267.

Gessner, M. O., and E. Chauvet. 2002. A case for using litter breakdown to assess functional stream integrity. Ecological Applications 12:498-510.

Gonçalves, J. F., M. GraçA, AND M. Callisto. 2006. Leaf-litter breakdown in 3 streams in temperate, Mediterranean, and tropical Cerrado climates. Journal of the North American Benthological Society 25:344-355.

Grattan, R. M., AND K. SuberKRopp. 2001. Effects of nutrient enrichment on yellow poplar leaf decomposition and fungal activity in streams. Journal of the North American Benthological Society 20:33-43.

Greenwood, J. L., A. D. Rosemond, J. B. Wallace, W. F. Cross, AND H. S. WEYERS. 2007. Nutrients stimulate leaf breakdown rates and detritivore biomass: bottom-up effects via heterotrophic pathways. Oecologia (Berlin) 151:637-649.

Gulis, V., V. Ferreira, AND M. A. S. GraçA. 2006. Stimulation of leaf litter decomposition and associated fungi and invertebrates by moderate eutrophication: implications for stream assessment. Freshwater Biology 51:1655-1669.

Gulis, V., L. MarvanovÁ, And E. Descals. 2005. An illustrated key to the common temperate species of aquatic hyphomycetes. Pages 153-168 in M. A. S. Graça, F. Bärlocher, and M. O. Gessner (editors). Methods to study 
litter decomposition: a practical guide. Springer, Dordrecht, The Netherlands.

Gulis, V., AND K. SuberKROPP. 2003. Leaf litter decomposition and microbial activity in nutrient-enriched and unaltered reaches of a headwater stream. Freshwater Biology 48:123-134.

Hieber, M., AND M. O. Gessner. 2002. Contribution of stream detritivores, fungi, and bacteria to leaf breakdown based on biomass estimates. Ecology 83:1026-1038.

Hladyz, S., M. O. Gessner, P. S. Giller, J. Pozo, and G. WOODWARD. 2009. Resource quality and stoichiometric constraints on stream ecosystem functioning. Freshwater Biology 54:957-970.

Hladyz, S., S. D. Tiegs, M. O. Gessner, P. S. Giller, G. Rîşnoveanu, M. Preda, M. Nistorescu, M. Schindler, AND G. WoODWARD. 2010. Leaf-litter breakdown in pasture and deciduous woodland streams: a comparison among three European regions. Freshwater Biology 55: 1916-1929.

Irons, J. G., M. W. Oswood, R. J. Stout, and C. M. Pringle. 1994. Latitudinal patterns in leaf litter breakdown: is temperature really important? Freshwater Biology 32: 401-411.

KARR, J. R. 1991. Biological integrity: a long-neglected aspect of water resource management. Ecological Applications $1: 66-84$.

KarR, J. R., AND E. W. Chu. 1999. Restoring life in running waters. Better biological monitoring. Island Press, Washington, DC.

KROM, M. D. 1980. Spectrophotometric determination of ammonia: a study of a modified Berthelot reduction using salicylate and dichloroisocyanurate. Analyst 105: 305-316.

KvÅLSETH, T. O. 1985. Cautionary note about $R^{2}$. American Statistician 39:279-285.

LeCerf, A., AND E. Chauvet. 2008a. Diversity and functions of leaf-decaying fungi in human-altered streams. Freshwater Biology 53:1658-1672.

LECERF, A., AND E. CHAUVET. 2008b. Intraspecific variability in leaf traits strongly affects alder leaf decomposition in a stream. Basic and Applied Ecology 9:598-607.

Lecerf, A., G. Risnoveanu, C. Popescu, M. O. Gessner, and E. CHAuvet. 2007. Decomposition of diverse litter mixtures in streams. Ecology 88:219-227.

Marvanová, L., and E. Descals. 1985. New and critical taxa of aquatic hyphomycetes. Botanical Journal of the Linnean Society 91:1-23.

McKie, B. G., G. Woodward, S. Hladyz, M. Nistorescu, E. Preda, C. Popescu, P. S. Giller, and B. MalmQvist. 2008. Ecosystem functioning in stream assemblages from different regions: contrasting responses to variation in detritivore richness, evenness and density. Journal of Animal Ecology 77:495-504.

Mendoza-Lera, C., J. Pérez, E. Descals, A. Martínez, O. Moya, I. Arostegui, and J. Pozo. 2010. Headwater reservoirs weaken terrestrial-aquatic linkage by slowing leaf-litter processing in downstream regulated reaches. River Research and Applications. doi: 10.1002/rra.1434
MerRITt, R. W., AND K. W. Cummins (editors). 1996. An introduction to the aquatic insects of North America. $3^{\text {rd }}$ edition. Kendall/Hunt Publishing Company, Dubuque, Iowa.

Mesquita, A., C. Pascoal, and F. CÁssio. 2007. Assessing effects of eutrophication in streams based on breakdown of eucalypt leaves. Fundamental and Applied Limnology 168:221-230.

Molinero, J., J. Pozo, AND E. GonzÁlez. 1996. Litter breakdown in streams of the Agüera catchment: influence of dissolved nutrients and land use. Freshwater Biology 36:745-756.

Monteiro, M. I. C., F. N. Ferreira, N. M. M. De Oliveira, And A. K. Ávila. 2003. Simplified version of the sodium salicylate method for analysis of nitrate in drinking waters. Analytica Chimica Acta 477:125-129.

Moss, B. 2008. The Water Framework Directive: total environment or political compromise? Science of the Total Environment 400:32-41.

Moulton, T. P. 1999. Biodiversity and ecosystem functioning in conservation of rivers and streams. Aquatic Conservation: Marine and Freshwater Ecosystems 9:573-578.

MülleR, B., M. Berg, Z. P. YaO, X. F. Zhang, D. WANG, AND A. Pfluger. 2008. How polluted is the Yangtze river? Water quality downstream from the Three Gorges Dam. Science of the Total Environment 402:232-247.

Niyogi, D. K., K. S. Simon, and C. R. Townsend. 2003. Breakdown of tussock grass in streams along a gradient of agricultural development in New Zealand. Freshwater Biology 48:1698-1708.

PASCOAL, C., AND F. CÁsSIO. 2004. Contribution of fungi and bacteria to leaf litter decomposition in a polluted river. Applied and Environmental Microbiology 70:5266-5273.

Pascoal, C., M. Pinho, F. Cássio, and P. Gomes. 2003. Assessing structural and functional ecosystem condition using leaf breakdown: studies on a polluted river. Freshwater Biology 48:2033-2044.

Paul, M. J., J. L. Meyer, and C. A. Couch. 2006. Leaf breakdown in streams differing in catchment land use. Freshwater Biology 51:1684-1695.

Pérez, J., M. Menéndez, S. Larrañaga, and J. Pozo. 2011. Inter- and intra-regional variability of leaf litter breakdown in reference headwater streams of northern Spain: Atlantic versus Mediterranean streams. International Review of Hydrobiology 96:105-117.

Pozo, J. 1993. Leaf litter processing of alder and eucalyptus in the Agüera stream system (North Spain) I. Chemical changes. Archiv für Hydrobiologie 127:299-317.

Pozo, J., A. Basaguren, A. Elósegui, J. Molinero, E. Fabre, AND E. Chauvet. 1998. Afforestation with Eucalyptus globulus and leaf litter decomposition in streams of northern Spain. Hydrobiologia 373/374:101-109.

QuinN, G. P., AND M. J. KeOUGH. 2002. Experimental design and data analysis for biologists. Cambridge University Press, Cambridge, UK.

Rabeni, C. F., K. E. Doisy, and L. D. Zweig. 2005. Stream invertebrate community functional responses to deposited sediment. Aquatic Sciences 67:395-402.

Ritininen, M. P., J. Davy-Bowker, and M. Dobson. 2009. Comparison of structural and functional stream assess- 
ment methods to detect changes in riparian vegetation and water pH. Freshwater Biology 54:2127-2138.

SAmpaio, A., P. Rodríguez-González, S. Varandas, R. M. Cortes, AND M. T. Ferreira. 2008. Leaf litter decomposition in western Iberian forested wetlands: lentic versus lotic response. Limnetica 27:93-106.

SpÄnhoff, B., C. Augspurger, And K. Küsel. 2007. Comparing field and laboratory breakdown rates of coarse particulate organic matter: sediment dynamics mask the impacts of dissolved nutrients on CPOM mass loss in streams. Aquatic Sciences 69:495-502.

SтоUт, R. J. 1989. Effects of condensed tannins on leaf processing in mid-latitude and tropical streams: a theoretical approach. Canadian Journal of Fisheries and Aquatic Sciences 46:1097-1106.

Suberkropp, K., AND E. Chauvet. 1995. Regulation of leaf breakdown by fungi in streams: influences of water chemistry. Ecology 76:1433-1445.

Tachet, H., P. Richoux, M. Bournaud, and F. UsseglioPolatera. 2002. Invertébrés d'eau douce. Systematique, biologie, écologie. CNRS Editions, Paris, France.

Verbeke, G., AND G. MolenberGhs. 2000. Linear mixed models for longitudinal data. Springer-Verlag, New York.

WALLACE, J. B., AND S. L. EgGERT. 2009. Benthic invertebrate fauna, small streams. Encyclopedia of Inland Waters 2:173-190.

Webster, J. R., AND E. F. BenfiEld. 1986. Vascular plant breakdown in freshwater ecosystems. Annual Review of Ecology and Systematics 17:567-594.

Webster, J. R., J. B. Wallace, and E. F. Benfield. 1995. Organic processes in streams of the Eastern United
States. Pages 117-187 in C. E. Cushing, K. W. Cummins, and G. W. Minshall (editors). Ecosystems of the world 22. River and stream ecosystems. Elsevier, New York.

Withers, P. J. A., AND H. P. JARviE. 2008. Delivery and cycling of phosphorus in rivers: a review. Science of the Total Environment 400:379-395.

WoOdWARD, G. 2009. Biodiversity, ecosystem functioning and food webs in freshwaters: assembling the jigsaw puzzle. Freshwater Biology 54:2171-2187.

Young, R. G., C. D. Matthaei, and C. R. Townsend. 2008. Organic matter breakdown and ecosystem metabolism: functional indicators for assessing river ecosystem health. Journal of the North American Benthological Society 27:605-625.

Young, R. G., C. R. Townsend, and C. D. Matthaei. 2004. Functional indicators of river ecosystem health - an interim guide for use in New Zealand. Cawthron report No. 870 Cawthron Institute, Nelson, New Zealand. (Available from: http://www.cawthron.org.nz/coastalfreshwater-resources/downloads/functional-indicatorsguide-final.pdf)

ZAR, J. H. 2010. Biostatistical analysis. $5^{\text {th }}$ edition. Pearson, Upper Saddle River, New Jersey.

Zweig, L. D., AND C. F. Rabeni. 2001. Biomonitoring for deposited sediment using benthic invertebrates: a test on 4 Missouri streams. Journal of the North American Benthological Society 20:643-657.

Received: 17 November 2010 Accepted: 28 June 2011 